\title{
DINAMIKA DAN REPRODUKSI KEKERASAN PELAJAR DI DENPASAR
}

\section{Imron Hadi Tamim}

Dosen Sosiologi FISIP Udayana

\begin{abstract}
This research aims to explore the students'violence, its dynamics and the reproduction of violence. As a young person, the student views that the meaning of personal identity is very important for his/her life to be existing in the social world. The "geng pelajar" is the social group which has contributed to students' personality. This research was held in four senior high schools in Denpasar. The researh used qualitative approach to inquiry the data. The Senior High School students in SMAN Denpasar, SMAN 2 Denpasar, SMAN 3 Denpasar and SMAN 7 Denpasar have many social groups called "geng". Then the gangs in those schools influenced the member of gangs. The reproduction of violence occurred in the gangs so that the violence was dynamic not static.
\end{abstract}

Keywords: student's violence, gangs, dynamic and reproduction

\section{PENDAHULUAN}

Kekerasan di kalangan pelajar sekolah menengah bukanlah kisah baru di Indonesia. Hal ini terbukti berdasarkan frekuensi tawuran pelajar yang kerap kali terjadi. Oleh karena itu tak heran apabila sebagian orang menganggap fenomena itu sebagai hal yang biasa dan bersifat sementara. Anggapan seperti ini terlalu berbahaya karena pelembagaan dan institusionalisi konflik dan kekerasan di ranah pendidikan dengan sendirinya menjelma sebagai rutinitas kekerasan yang terintegrasi ke dalam institusi tersebut yang pada akhirnya berubah menjadi pola perilaku.

Sebenarnya akar permasalahan kekerasan di kalangan pelajar bukan persoalan identitas semata. Ada berbagai ragam faktor, di antaranya faktor personal, faktor struktural dan kultural pelajar, baik di dalam lembaga pendidikan maupun luar institusi pendidikan (keluarga, masyarakat, lingkungan) tempat para pelajar berinteraksi sosial.

Berbicara mengenai konteks kekerasan pelajar, pada tahun 2011 KPAI mencatat ada 128 kasus kekerasan pelajar. Pada tahun 2012, kasus 
kekerasan pelajar naik menjadi 147 dengan korban jiwa 82 anak. (http://news.detik.com/berita/2124481, diakses tanggal 13 Februari 2013).

Merebaknya fenomena kekerasan merupakan bentuk kenakalan remaja yang terjadi dalam dunia pelajar dan mengandung permasalahan yang sangat kompleks, jika fenomena ini tidak segera dicegah maka akan merusak dan memperpuruk citra dunia pendidikan, khususnya penyelenggara pendidikan. Hal ini tertentu sangat disayangkan bagi Kota Denpasar ditengah upayanya untuk mempromosikan dan memperkokoh identitasnya sebagai ikon "Bali Santhi”. Tentu menjadi tantangan tersendiri bagi pemerintah Denpasar khususnya dinas atau instansi penyelenggara pendidikan untuk menyelenggarakan pendidikan yang humanis dan bebas dari aksi dan tindakan kekerasan.

Di sisi lain, maraknya kekerasan yang terjadi di tengah-tengah kalangan pelajar menebar ancaman, bukan hanya bagi citra sekolah yang tersangkut, akan tetapi juga dirasakan oleh para orang tua yang ingin menyekolahkan anak mereka di sekolah tersebut. Berdasarkan preresearch mengenai konflik dan kekerasan di Denpasar dapat diduga bahwa akar permasalahan konflik kaum pelajar di Denpasar adalah terkait dengan citra sekolah di bidang tertentu. Misalnya persaingan atau kompetisi antara pelajar SMAN 1 Denpasar dengan pelajar SMAN 3 Denpasar di bidang karya ilmiah remaja, dan antara pelajar SMAN 2 Denpasar dengan pelajar SMAN 7 Denpasar di bidang olahraga basket.

Berdasarkan kondisi inilah, penelitian ini diarahkan untuk mencari akar permasalahan konflik, dinamika konflik serta mengupayakan bagaimana menciptakan iklim Bali (Denpasar) sebagai kota pariwisata yang damai jauh dari nuansa dan praktek kekerasan. Di samping itu, penelitian ini juga mengkaji efektifitas peran dan upaya sekolah dan para stakeholders pendidikan dalam mengantisipasi tindak kekerasan para pelajar. Hal ini didasarkan bahwa sekolah sebagai salah satu institusi pendidikan dalam konteks kekerasan pelajar secara tidak langsung ikut bertanggungjawab terhadap tindak dan aksi kekerasan yang dilakukan oleh para pelajar. 


\section{METODE PENELITIAN}

Penelitian ini menggunakan metode kualitatif dengan pendekatan deskriptif analitis-komparatif. Penelitian ini menggunakan strategi studi kasus untuk meneliti kasus kekerasan pelajar SMA di Denpasar. Penelitian studi kasus yang dipakai adalah intrinsic case study. Jenis studi ini dilakukan untuk memahami secara lebih detail mengenai kasus kekerasan pelajar, mengetahui secara intrinsic fenomena kekerasan, keteraturan dan kekhususan terhadap kasus kekerasan. Karena studi kasus ini dilakukan di beberapa sekolah yang mempunyai karakteristik berbeda, maka metode analisis yang digunakan adalah analisis deskriptif-komparatif.

Penelitian ini dilakukan di SMAN 1 Denpasar, SMAN 3 Denpasar, SMAN 2 Denpasar dan SMAN 7 Denpasar. Penentuan lokasi penelitian dilakukan berdasarkan karakteristik pendidikan di sekolah. Dipilihnya sekolah SMAN 1 Denpasar dan SMAN 3 Denpasar sebagai subyek penelitian adalah karena para pelajar di sekolah ini seringkali terlibat aksi kekerasan seperti tawuran, namun pelajar di sekolah ini juga mendapatkan prestasi akademis.
Data yang digunakan dalam penelitian ini bersumber pada data primer dan data sekunder. Pengumpulan data primer dilakukan melalui observasi dan wawancara. Wawancara dilakukan dengan menggunakan dua cara; pertama wawancara terstruktur dengan menggunakan interview guide dan kedua adalah wawancara mendalam yang digunakan untuk menelusuri informasi sedalam-dalamnya guna memperoleh data terkait dengan penelitian di atas.

Data sekunder diperoleh melalui pengumpulan data yang berbentuk dokumenasi teks, foto -foto, dokumendokumen terkait dengan konflik dan kekerasan pelajar di berbagai institusi lembaga pemerintah maupun swasta, di sekolah maupun di institusi lain yang memungkinkan tersedianya data sekunder.

Pemilihan informan ditentukan secara purposive dan snowballing. Dalam melakukan penelitian pada awalnya dipilih infoman secara sengaja (purposive) disesuaikan dengan rumusan masalah. Pemilihan informan juga menggunakan prinsip snowballing, artinya jumlah informan semakin bertambah sesuai dengan rekomendasi informan sebelumnya. 
Seperti dalam penelitian dalam beberapa bentuk : pertama kualitatif pada umumnya, data yang diskriminasi terhadap perbedaan, kedua, diperoleh dari hasil observasi di lapangan dan wawancara dengan semangat corp/almamater.

Diskriminasi yang dilakukan oleh informan dijadikan bahan utama dalam analisis. Menurut Yin (2006: 133), di dalam studi kasus ada tiga teknik analisis data; pertama penjodohan pola, kedua, pembuatan pola dan ketiga analisis deret waktu. Selain itu analisis data juga menggunakan tiga pola Miles dan Hubberman yaitu reduksi data, penyajian data, serta penarikan kesimpulan dan verifikasi data (Denzin, 1994: 428-429; Milles dan Huberman, 1992: 16-19). Semua tahapan ini dilakukan secara interaktif saling berhubungan selama dan sesudah pengumpulan data.

\section{HASIL DAN PEMBAHASAN}

\section{a. Benih-Benih Kekerasan \\ Pelajar di Sekolah}

Berdasarkan data penelitian dapat disimpulkan bahwa kekerasan fisik di kalangan pelajar di sekolah SMAN Denpasar tergolong jarang terjadi. Namun demikian bukan berarti bahwa benih-benih kekerasan di dalamnya tidak nampak atau muncul. Benih-benih kekerasan di beberapa sekolah yang menjadi subjek penelitian menjelma pelajar SMAN di Denpasar adalah diskriminasi terhadap perbedaan yang dimiliki oleh orang lain. Perbedaan ini biasanya menyangkut banyak hal, misalnya mereka (pelajar) yang berprestasi dan bermasalah, pelajar "baik" dan pelajar "nakal", pelajar rajin dan pelajar "malas", pelajar "pandai" dan pelajar "bodoh". Struktur dan kultur sekolah secara tidak langsung juga memberikan legitimasi terhadap pelajar yang berprestasi, baik secara akademik maupun non akademik seperti kegiatan ekstra-kurikuler. Legitimasi ini disampaikan sekolah melalui penghargaan kepada individu yang telah membuat citra sekolah "baik" dan "penuh prestasi". Perlakuan yang tidak sama oleh pihak sekolah dirasakan diskriminatif oleh para pelajar lain yang tidak mempunyai prestasi.

Benih kekerasan lainnya yaitu semangat corps/almamater yang sering disalah-artikan oleh para pelajar. Kecintaan terhadap almamater membentuk sikap fanatik terhadap almamater. Bentrokan antara pelajar 
antar sekolah lebih banyak disebabkan oleh sikap fanatisme berlebihan terhadap almamater. Dalam konteks sekolah menengah di Denpasar (SMAN 1 Denpasar, SMAN 2 Denpasar, SMAN 3 Denpasar dan SMAN 7 Denpasar), kecintaan dan pembelaan terhadap almamater/corp para pelajar dalam kegiatan-kegiatan seperti PORJARSENI (Pekan Olah-Raga Pelajar Dan Seni) seringkali menjadi pemicu perkelahian dan kekerasan pelajar.

\section{b. Munculnya Social Group (Kelompok-Kelompok Pelajar) di Sekolah}

Dinamika dan reproduksi kekerasan dilakukan oleh pelajar melalui saluran-saluran tertentu. Saluran tersebut berfungsi sebagai tempat para pelajar untuk mengartikulasikan diri mereka ke dalam sebuah grup atau kelompok. Di dalam grup atau kelompok inilah terjadi produksi identitas serta simbol-simbol tertentu yang membedakan diri mereka dengan orang lain (the others). Berikut ini adalah grup atau kelompok-kelompok sosial para pelajar SMA di lokasi penelitian; yaitu di SMAN 1 Denpasar, SMAN 2 Denpasar, SMAN 3 Denpasar dan SMAN 7 Denpasar.

\section{SMAN 1 Denpasar}

\section{Temuyuk Crew (TMC)}

Geng ini dibentuk pada tahun 2008. Tujuan dibentuknya geng ini adalah untuk menambah ikatan persahabatan antar teman. Persyaratan untuk masuk geng ini tidak ada, kalau ingin ikut, ya ikut saja, namun anggota geng tetap mencari anggota dan lebih sering mencari adik-adik kelas terutama anak baru. Menurut informasi dari informan yang didapat, ketua geng adalah pendiri awal geng tersebut, namun untuk generasi berikutnya ketua geng dipilih atas kesepakatan semua anggota, yaitu salah satu dari anggota yang cocok menjadi ketua geng. Anggota TMC memang didominasi oleh pelajar laki-laki, namun ada juga beberapa pelajar perempuan yang ikut di dalamnya. Jumlah pasti anggota laki-laki maupun perempuan tidak diketahui, karena tidak ada pendataan secara jelas. Masalah yang ditimbulkan oleh TMC sejauh ini hanyalah permasalahan dengan geng lainnya dalam satu sekolah, yaitu AME. Biasanya yang dipermasalahkan adalah mengenai perekrutan anggota baru, yaitu berebut anak-anak kelas sepuluh untuk menjadi anggota geng, tidak sampai adu fisik, 
hanya sekedar saling ejek dan menyindir di antara kedua geng tersebut. Untuk permasalahan di luar sekolah menurut informasi yang didapatkan sejauh ini belum ada. Kegiatan yang sering dilakukan geng ini biasanya kumpulkumpul dan membuat bazar untuk mengumpulkan dana kas geng. Uang kas tersebut digunakan membuat bazar selanjutnya. Pihak sekolah mengetahui adanya geng ini, namun belum ditindak seperti dibubarkan atau mendapat teguran, maka sampai saat ini TMC masih tetap ada.

\section{I Love Tunang Timpal (AME)}

Menurut Dwiki yang pernah menjadi anggota AME sewaktu kelas sepuluh, dia tidak mengetahui tahun berapa AME terbentuk, namun menginjak kelas sebelas, responden ini tidak lagi tergabung dalam AME. Geng ini dibentuk untuk menjalin pertemanan yang lebih erat. Pemilihan ketua geng ini dilakukan hanya berdasarkan kesepakatan bersama. Anggota AME biasanya adalah anak-anak pemain bola basket. Mereka biasanya anak-anak yang popular. Perekrutan anggota tidak ada paksaan. Anggota AME lebih banyak laki-laki daripada perempuan. Anggota perempuan biasanya adalah pacar atau teman dari anggota AME yang laki-laki. Kegiatan AME biasanya ngumpul bareng dan membuat bazar. Biasanya bila mereka mengadakan bazar, anggota baru AME diwajibkan datang ke tempat bazar untuk melayani tamu (pembeli) yang menukar kupon dengan makanan, baik dimakan di tempat atau dibawa pulang. Responden kurang begitu tahu mengenai penggunaan uang hasil bazar. Sejauh ini AME belum pernah memiliki kasus di luar sekolah. Geng ini hanya berebut anggota baru dengan TMC seperti yang disebutkan di atas. Kegiatan geng AME ini di luar sekolah biasanya menjadi supporter apabila sekolah ikut lomba, seperti bola basket, paduan suara ataupun lomba lainnya yang membutuhkan banyak supporter. Geng ini sampat saai ini masih ada di SMAN 1 Denpasar.

\section{SMAN 2 Denpasar}

\section{Ability}

Geng ini (Ability) terbentuk sejak 2006. Menurut para responden, tujuan dari terbentuknya geng ini adalah untuk menjaga solidaritas antar teman serta untuk mengakrabkan diri dengan sesama dan mempererat hubungan pertemanan. Anggota Ability bermarkas 
di warung Fima yang terletak tepat di seberang sekolah mereka dari arah Jalan Jendral Sudirman. Tidak ada persyaratan untuk masuk sebagai anggota dalam geng ini, namun biasanya anggota geng mencari anggota baru ketika ada siswa baru di sekolahnya. Menurut informasi yang didapat, ketua geng yang pertama kali adalah anak (pelajar) yang mendirikan geng tersebut dan memiliki banyak andil dalam pembentukan geng ini, namun pada generasi selanjutnya, biasanya pemilihan ketua geng dilakukan berdasarkan voting atau musyawarah. Secara keseluruhan, anggota Ability didominasi oleh anak laki-laki, namun ada juga beberapa anak perempuan yang ikut di dalamnya, sementara jumlah pasti anggota laki-laki maupun perempuan tidak diketahui secara pasti, karena tidak adanya pendataan secara jelas. Untuk masalah yang ditimbulkan oleh Ability, sejauh ini hanyalah permasalahan dengan geng lainnya di satu sekolah yaitu, Plecing Crew. Kedua geng ini pernah bersinggungan satu sama lain dikarenakan salah paham ataupun permasalahan pribadi, permasalahan tersebut pernah sampai pada tindakan fisik seperti bentrok antar grup sekitar tahun 2012. Namun belakangan ini tindakan seperti itu tidak pernah terjadi lagi, saat ini tindakannya hanya sekedar ejek-ejekan dan berlalu begitu saja. Kegiatan yang sering dilakukan geng ini biasanya kumpul-kumpul dan membuat bazar untuk mengumpulkan uang kas geng. Uang tersebut agar dapat digunakan membuat bazar selanjutnya dan terkadang dipergunakan untuk sekedar berpesta seperti dengan mengadakan kegiatan magang dengan sesama anggota geng, atau sekedar sebagai uang untuk mereka liburan di villa. Terkadang dana dari bazar mereka kumpulkan untuk kegiatan bakti sosial juga. Pihak sekolah tidak terlalu ikut campur soal kedua grup, karena ketika mereka mempunyai permasalahan ataupun sampai pada tindakan fisik, kedua grup berada di luar jam sekolah dan di luar wilayah sekolah serta tidak membawa nama dan citra sekolah, tapi lebih kepada gengsi kedua grup. Namun terkadang apabila pihak sekolah atau satpam melihat ada siswanya yang melakukan tindakan kekerasan fisik di sekitar area sekolah, maka siswa tersebut dipanggil oleh kepala sekolah dan diberikan surat peringatan, bahkan ada 
pelaku yang sampai dikeluarkan dari sekolah.

\section{Plecing Crew}

Plecing Crew terbentuk pada 2008 sebagai sempalan dari grup Ability. Penamaan "plecing" diambil dari salah satu makanan asal Bali. Pemilihan nama ini oleh para anggota kelompok dimaksudkan agar nama kelompoknya berbeda dengan kelompok lainnya serta agar mudah diingat. Tujuan pembentukan geng ini sama seperti geng pada umumnya, yakni untuk mempererat tali persaudaraan antar anggota. Biasanya geng ini mencari anggota baru ketika masa-masa MOS (masa orientasi sekolah) di sekolahnya. Target mereka adalah siswa-siswi baru. Pemilihan ketua geng juga sama seperti dilakukan oleh Ability, yakni berdasarkan voting dan musyawarah. Anggota dari Plecing Crew terdiri dari anak-anak (pelajar) laki-laki dan anak-anak (pelajar) perempuan dengan jumlah anggota laki-laki lebih banyak daripada anggota perempuan, namun secara pasti tidak diketahui jumlahnya karena tidak ada pendataan. Plecing Crew dengan Ability pernah bersinggungan karena salah paham dan karena permasalahan pribadi. Permasalahan tersebut pernah sampai pada tindakan kekerasan fisik, seperti bentrok antar grup pada 2012. Namun belakangan ini tindakan seperti itu tidak pernah terjadi lagi.

\section{SMAN 3 Denpasar}

\section{Zeus}

Kapan awal mula terbentuknya Zeus tidak diketahui, namun geng ini merupakan kumpulan anak-anak kelas dua belas Jadi otomatis apabila anakanak (para pelajar) di sekolah tersebut sudah naik kelas dua belas maka mereka langsung masuk Zeus. Geng ini dibentuk agar kekompakan antara anak-anak kelas dua belas lebih erat lagi. Ketuanya sendiri dipilih atas kesepakatan bersama, siapa yang dianggap cocok maka dialah yang menjadi ketua geng. Untuk anggotanya lebih banyak laki-laki, perempuannya hanya segelintir karena yang perempuan merupakan pacar anggota laki-laki. Kegiatan yang dilakukan tetap seperti pada umumnya geng-geng di sekolah, yakni kumpulkumpul di kantin sekolah maupun di warung dekat sekolah. Zeus juga sering mengadakan bazzar. Biasanya uang hasil bazzar dikumpulkan untuk membuat bazzar selanjutnya, atau jalan-jalan dengan anggota atau membuat baju geng 
Zeus. Zeus pernah membuat masalah di luar sekolah sehigga warga sekitar sekolah marah karena anggota geng tersebut sembarangan membuat grafiti (coretan) di tembok-tembok rumah milik warga. Selain permasalahan tersebut, pernah juga Zeus terlibat adu fisik dengan geng TDF hingga mengakibatkan anggota TDF terluka. Permasalahan dengan geng sekolah lain juga pernah terjadi, biasanya dalam kegiatan PORSENIJAR, itupun mereka membaur sebagai suporter sekolah, namun hanya sebatas ejek-ejekan tidak sampai adu fisik. Pihak sekolah pernah menindak Zeus, anggota-anggotanya ada yang dijemur kemudian baju geng mereka dikumpulkan dan dibakar, namun sampai saat ini Zeus tidak bubar. Para anggota geng ini tidak senakal angkatan-angkatan sebelumnya.

\section{Dente Familia (TDF)}

Tidak banyak informasi yang didapat mengenai TDF karena geng ini sudah bubar sejak tamatan terakhir tahun 2012. Tujuan dibentuknya geng ini sama saja dengan geng lainnya yaitu untuk menambah pertemanan, namun anggotanya sendiri tidak hanya anggota kelas dua belas namun semuanya dapat ikut bergabung. Perekrutan anggota tidak jelas bagaimana mekanismenya, hanya saja salah satu anggota TDF ini merupakan anak dari mantan walikota Denpasar yakni Bapak Puspayoga, sehingga terkesan bahwa TDF dilindungi oleh pihak yang kuat. TDF sendiri hanya pernah bermasalah dengan Zeus mengenai salah paham antar kedua anggota geng sehingga timbul adu fisik. Anggota sendiri didominasi oleh siswa laki-laki. Pada saat pihak sekolah menindak Zeus dengan menjemur anggotanya dan membakar kaos geng Zeus, TDF sendiri tidak ditindak oleh pihak sekolah, menurut Rafista Sena dan Mahendra Yudha mungkin karena ada anggotanya anak orang penting di pemerintahaan jadi pihak sekolah tidak melakukan tindakan apa-apa kepada TDF. Menurut Mahendra Yudha, kegiatan seperti biasa kumpul-kumpul layaknya geng lain maupun mengadakan bazar, maupun mengumpulkan anggotanya untuk menjadi suporter sekolah di kompetisi antar sekolah. Bubarnya TDF sendiri tidak diketahui alasannya.

\section{Atomic Family (AMF)}

AMF merupakan geng baru di SMAN 3 Denpasar, setelah bubarnya TDF baru AMF dibentuk langsung pada 
2012. Anggota AMF awal mulanya yang diutamakan anak-anak angkatan 2012, namun saat ini sudah merekrut angkatan adik kelas 2013, namun bila ada angkatan senior yang ingin bergabung dipersilahkan saja. Untuk ketua AMF sendiri dipilih dari pencetus geng AMF di angkatan 2012. Anggota AMF bercampur antara laki-laki dan perempuan jadi jumlah pastinya tidak jelas, karena pada saat kumpul-kumpul tidak semua anggota bisa hadir, kadangkadang yang berkumpul hanya segelintir saja jadi pendataan pun menjadi susah. AMF yang tergolong geng baru belum pernah memiliki masalah apapun dengan Zeus maupun sekolah lainnya, bisa dikatakan geng ini masih dalam taraf yang aman-aman saja. Menurut Ayu Sukma Pramestiari, pihak sekolah belum mengetahui keberadaan geng AMF, karena baru dan pengorganisiran anggota belum jelas.

\section{SMAN 7 Denpasar}

\section{King of Fool (KOF)}

Awal berdirinya geng ini diprakarsai oleh siswa-siswa kelas dua belas tepatnya pada tahun 2008. Tujuan dari terbentuknya geng ini adalah untuk menjaga solidaritas antar teman serta untuk mengakrabkan diri dengan sesama dan mempererat hubungan pertemanan. Geng ini bermarkas di Jalan Jempiring Denpasar. Tidak ada persyaratan khusus untuk masuk dalam geng ini, namun biasanya anggota geng mencari anggota baru ketika adanya siswa baru di sekolahnya yakni ketika MOS. Perekrutan anggota sendiri tidak ada paksaan. Anggota KOF sendiri lebih banyak anggota laki-lakinya daripada yang perempuan, anggota perempuan sendiri biasanya adalah pacar atau teman dari anggota KOF yang laki-laki. Untuk pemilihan ketua geng yang pertama kali saat geng terbentuk, dipilih berdasarkan orang yang mendirikan geng tersebut dan banyak mengambil andil dalam tercetusnya geng ini, namun pada generasi selanjutnya, biasanya berdasarkan voting atau musyawarah. Kegiatan KOF biasanya sekedar berkumpul bersama dan membuat bazar. Biasanya saat bazzar, anggota baru KOF diwajibkan untuk datang ke tempat bazzar untuk melayani tamu bazar. Untuk uangnya sendiri, biasanya dipergunakan sama seperti geng-geng pada umumnya yaitu untuk berfoyafoya. Untuk masalah di luar sekolah, sejauh ini KOF pernah terlibat kasus di 
luar sekolah, namun untuk kapan pastinya, tidak diketahui dengan jelas. Biasanya kasus-kasus yang terjadi pada geng-geng sekolah seperti salah paham dan lainnya. Kegiatan geng ini di luar sekolah biasanya menjadi suporter apabila sekolah ikut lomba, seperti basket, paduan suara ataupun yang lainnya yang membutuhkan suporter yang banyak. Geng ini masih ada sampat saai ini di SMAN 7 Denpasar. Pihak sekolah mengetahui keberadaan grupgrup tersebut dan mengizinkan kegiatankegiatannya selama tujuan grup-grup tersebut untuk hal-hal positif serta tidak merugikan sekolah.

\section{Lavista}

Awal mula terbentuknya geng ini tidak diketahui secara pasti, namun geng ini dipastikan terbentuk setelah adanya geng KOF di SMA 7 Denpasar. Geng ini dibentuk agar menjaga kekompakan antara teman-teman agar jauh lebih erat ke depannya. Untuk ketuanya sendiri dipilih atas kesepakatan bersama. Anggotanya lebih banyak anak laki-laki, sedangkan perempuannya hanya beberapa karena kebanyakan merupakan pacar anggota laki-laki. Geng ini memiliki kegiatan yang dilakukan seperti pada umumnya geng-geng di sekolah, yakni kumpul-kumpul di kantin sekolah maupun di warung dekat sekolah. Lavista juga terkadang mengadakan bazzar, dan uang hasil bazar dikumpulkan untuk kegiatan pribadi mereka seperti geng kebanyakan dan sisanya untuk membuat bazar selanjutnya, atau sekedar jalan-jalan dengan anggota. Lavista pernah membuat masalah di luar sekolah serta pernah bersinggungan dengan KOF sebagai geng yang tertua di sekolah. Permasalahan ini terjadi karena adanya sikap saling mengejek yang akhirnya menimbulkan adu mulut antara kedua geng ini. Hingga saat ini geng ini masih ada di SMA 7 Denpasar. Pihak sekolah mengetahui keberadaan grup-grup tersebut dan mengizinkan selama tujuan daripada grup-grup tersebut untuk halhal positif serta tidak merugikan nama sekolah.

\section{c. Social Group (geng pelajar) sebagai Ruang Produksi Kekerasan}

Geng Pelajar merupakan media atau sarana bagi para pelajar yang tergabung di dalamnya untuk mengartikulasikan diri dan memaknai kedirian (self) mereka sebagai bagian dari kelompok dengan karakteristik yang 
berbeda antara satu kelompok dengan kelompok lain dalam satu sekolah. Di dalam komunitas sekolah, para pelajar yang tergabung dalam kelompok "geng sekolah" menghabiskan waktunya dalam kelompok tersebut. "Geng sekolah" dalam hal ini memainkan peranan yang penting dalam membentuk sikap dan perilaku setiap anggotanya. Relasi sesama anggota melalui dinamika ingroup (kelompok) yang intensif menumbuhkan rasa solidaritas pertemanan diantara para anggota.

Dalam hal ini, "geng pelajar" berfungsi sebagai ruang dimana telah berlangsung proses produksi dan reproduksi. "geng pelajar" membuat aturan main yang mengikat para anggotanya dan memaksa anggotanya tunduk dan patuh terhadap aturan main geng. Sebaliknya, para anggota "geng pelajar" menganggap bahwa identitas geng sebagai identitas kelompok mereka yang berbeda dengan kelompok lain. Aktifitas produksi "geng pelajar" diejawantahkan dalam berbagai kegiatan dengan tujuan agar semakin mempererat ikatan sesama anggota serta memperoleh citra baik di mata orang lain.
"Geng pelajar" memproduksi berbagai atribut untuk menunjukkan eksistensinya baik di depan anggotanya sendiri terutama eksistensinya bagi kelompok di luar kelompok geng. Dengan melalui berbagai kegiatan tersebut, geng pelajar berharap agar kelompoknya mendapatkan pujian bukan cemoohan, terutama untuk menjaga keberlangsungan dan eksistensi geng itu sendiri. Meskipun geng tidak mempunyai sistem pengelolaan keuangan secara profesional. Namun para anggotanya mempunyai kreatifitas dalam menggalang dana untuk kegiatan sosial, misalnya melalui kegiatan bazaar, dan lain-lain.

\section{KESIMPULAN}

Dinamika kekerasan pelajar SMA di beberapa sekolah negeri di Denpasar (SMAN 1 Denpasar, SMAN 2 Denpasar, SMAN 3 Denpasar dan SMAN 7 Denpasar) berlangsung dalam konteks persaingan dan kompetisi yang terjadi di internal sekolah maupun dengan pihak eksternal (sekolah lain). Munculnya kelompok pelajar (geng) di sekolah-sekolah di atas mengindikasikan bahwa benih-benih kekerasan tumbuh 
dan berkembang di lingkungan sekolah sebagai perwujudan baru.

"Geng" yang ada di sekolah menjadi media atau sarana dan ruang bagi reproduksi kekerasan yang dilakukan oleh para pelajar. Reproduksi kekerasan berlangsung secara hierarkis antar angkatan serta melalui perekrutan anggota baru dalam setiap tahunnya. "Geng-geng" memainkan peran penting dalam membentuk karakter dan kepribadian anggotanya. Aturan main.

\section{DAFTAR PUSTAKA}

Abubakar, Irfan dan Chaider S.B.2006.Modul Resolusi Konflik Agama \& Etnis Di Indonesia. Jakarta:PBB UIN Syahida Jakarta.

Denzin, Norman K. dan Yvonna S. Lincoln (editors).1994. Handbook of Qualitative Reseearch. Thousand Oaks, London, New Delhi: Sage Publications.

Galtung, Johan.2003. Studi Perdamaian: Perdamaian dan Konflik,Pembangunan dan Peradaba., terj. Asnawi-Syafrudin. Surabaya: Pustaka Eureka.

Hermawati Istiana. Faktor-Faktor Yang Mempengaruhi Pelajar Terlibat Tawuran Pelajar. Dalam Media Informasi Penelitian Kesejahteraan Sosial Edisi 179. Tahun Ke 28 Juli-
September 2004. Yogyakarta: B2P3KS.

Koesoma, Doni.2007. Pendidikan Karakter; Strategi Mendidik Anak Di Zaman Modern. Jakarta:PT.Grasindo.

Milles, B.Matthew dan A. Michael Huberman.1992. Analisis Data Kualitatif. Jakarta: UI Press.

Raihana, Hani.2007. Negara Di Persimpangan Jalan Kampusku. Yogyakarta:Kanisius bekerjasama dengan Impulse.

Thomas Santoso, dkk. 2000. Teori-Teori Kekerasan. Jakarta: PT. Ghalia Indonesia.

Uyoh, Sadulloh. 2003. Pengantar Filsafat Pendidikan. Bandung: Alfabetha.

Yin, Robert K. 2006. Studi Kasus: Desain dan Metode. Penerjemah M. Djauzi Muzakir. Jakarta: Raja Grafindo Persada.

Sumber Internet http://news.detik.com/berita/2124481/ko mnas-pa-147-tawuran-pelajarpecah-selama-2012-82-anak-tewas, diakses tanggal 13 februari 2013. 